\title{
Indoor cycling training in rehabilitation of patients after myocardial infarction
}

\author{
Dagmara Gloc ${ }^{1}$, Zbigniew Nowak², Agata Nowak-Lis², Tomasz Gabryś3 , Urszula Szmatlan-Gabrys4, \\ Peter Valach ${ }^{3}$ and Anna Pilis ${ }^{5}$
}

\begin{abstract}
Background: Standard endurance training used from the second stage of cardiac rehabilitation has many common features with indoor cycling training which is used in fitness clubs. In the study, an attempt was made to evaluate the usefulness of this form of training in a 24-day rehabilitation program for patients after myocardial infarction. The study examined a group of 64 patients ( $51.34 \pm 8.02$ years) who were divided into two groups: the IC group (32 patients aged $53.40 \pm 4.31$ years) with indoor cycling training instead of standard endurance training; and the ST group (32 patients aged $55.31 \pm 6.45$ years) performing standard training. The level of exercise tolerance (cardiopulmonary exercise testing on a treadmill-Bruce's protocol), hemodynamic indicators of the left ventricle (echocardiography) and blood lipid profile (laboratory test) were assessed.

Results: In the IC group there was a significant increase in the test duration ( $9.21 \pm 2.02 \mathrm{vs} 11.24 \pm 1.26 \mathrm{~min}$; $p<0.001)$, the MET value $(9.16 \pm 1.30$ vs $10.73 \pm 1.23 ; p=0.006)$ and $\mathrm{VO}_{2} \max (37.27 \pm 3.23$ vs $39.10 \pm 3.17 \mathrm{ml} / \mathrm{kg} / \mathrm{min}$; $p<0.001)$. Parallel changes were observed in the ST group, where the following parameters improved: the test duration ( $9.41 \pm 0.39$ vs $10.91 \pm 2.22 ; p<0.001)$, MET value ( $8.65 \pm 0.25$ vs $9.86 \pm 1.12 ; p=0.002)$ and $\mathrm{VO}_{2} \max (36.89 \pm 6.22$ vs $38.76 \pm 3.44 ; p<0.001$ ). No statistically significant changes were found in the hemodynamic indices of the left ventricle and the lipid profile. Also, the intergroup analysis did not show any statistical significance.

Conclusion: Based on the research results, it was found that indoor cycling training in the second phase of cardiac rehabilitation is a safe form of therapy and therefore may be an interesting alternative method to the classic bicycle ergometer exercise in the stage of early cardiac rehabilitation.
\end{abstract}

Keywords: Myocardial infarction, Cardiac rehabilitation, Indoor cycling

\section{Introduction}

Traditional physical training, in line with the existing standards of management, which begins in the second stage of cardiac rehabilitation, is well known and described [1-3]. Few publications deal with the issue of the effectiveness of innovative forms of training in patients with diseases of the cardiovascular system [4-6]. The ever younger age of cardiac patients, the progress of

*Correspondence: agata.nowak@awf.katowice.pl

2 Department of Physiotherapy, Jerzy Kukuczka Academy of Physical Education, 40-065 Katowice, Poland

Full list of author information is available at the end of the article diagnostics and the development of interventional and surgical treatment methods require the gradual introduction of various forms of physical training. Adapting the rehabilitation programs to the possessed skills based on previous experience in the field of activity is becoming a key solution in the selection of training programs in modern cardiac rehabilitation. One such form is indoor cycling [7-9]. It is a form of aerobic interval training similar to the traditional training recommended in the second stage of rehabilitation, but with a slightly different course. Participants are not divided into beginners and advanced, because each person during the course of classes can modify loads or positions according to original author(s) and the source, provide a link to the Creative Commons licence, and indicate if changes were made. The images or other third party material in this article are included in the article's Creative Commons licence, unless indicated otherwise in a credit line to the material. If material is not included in the article's Creative Commons licence and your intended use is not permitted by statutory regulation or exceeds the permitted use, you will need to obtain permission directly from the copyright holder. To view a copy of this licence, visit http://creativecommons.org/licenses/by/4.0/. The Creative Commons Public Domain Dedication waiver (http://creativeco mmons.org/publicdomain/zero/1.0/) applies to the data made available in this article, unless otherwise stated in a credit line to the data. 
their own abilities $[10,11]$. The training imitates cycling in two basic types of terrain-flat and hilly. Riding can take place with and without contact of the arms with the steering wheel, in a sitting and standing position. It is already possible to change the position of the hands (1. Close, 2. Open, 3.Standing), allowing a variety of rehabilitation activities. The techniques used in indoor cycling reflect road cycling or in professional cycling sports and are divided into: seated flat (SF) cadence $80-120 \mathrm{rpm}$, seated climb (SC) cadence 60-80 rpm, standing flat (StF) cadence $80-120 \mathrm{rpm}$, standing climbing (StC) cadence 60-80 rpm), combo (Co) cadence 60-80-120 rpm, sprint flat $(\mathrm{SpF})$ and sprint climb $(\mathrm{SpC})$ cadence, maximum 100-110 rpm. The presented diversity of solutions used during exercise on a bicycle creates the possibility of conducting frequently changing classes in terms of exercise technique. An additional attraction of such training is the use of music, which makes it possible to determine the intensity of the traveled section, as well as its profile. The most frequently used music genres for classes are pop, techno, hip-hop, disco, and reggae.

The purpose of the class determines the profile, which can be:

- "active regeneration"/pro-health training (50-65\% HRmax),

- "endurance low/fat burning" (65-75\% HRmax)

- "endurance" (75-90\% HRmax)

- "climbing" (75-85\% HRmax),

- "interval" (65-85\% HRmax)

- "challenge" (85-100\% HRmax)

- "first time/express" (65-75\% HRmax) [7.8].

Scientific reports confirm the effective impact of indoor cycling training on cardiovascular and respiratory efficiency, reduction of adipose tissue and the risk of developing cardiovascular diseases in people without cardiovascular diseases [12-17]. The research conducted so far indicates the validity of undertaking research aimed at assessing the use of indoor cycling training as an alternative form to traditional endurance training in the primary and secondary prevention of cardiovascular diseases.

Due to the lack of reports on the possibilities of using indoor cycling training in cardiac rehabilitation programs, an experiment was conducted to determine the effect of such training on the level of exercise tolerance and hemodynamic indices of the left ventricle in patients after a heart attack.

The following research questions were formulated:

1. Can indoor cycling training, like standard endurance training, improve exercise tolerance (assessed by an exercise test) and change hemodynamic indicators of the left ventricle (assessed by echocardiography) and lipid profile (assessed using a laboratory method) in patients after myocardial infarction?

2. Can indoor cycling training be an alternative to standard endurance training commonly used in stage II rehabilitation?

\section{Hypotheses}

- Indoor cycling training may improve exercise tolerance, left ventricular hemodynamic indices and the lipid profile of patients after a heart attack.

- Indoor cycling training can be an alternative to standard endurance training used during the second stage of cardiac rehabilitation.

\section{Material and methods \\ Participants}

The study included 64 men (51.34 \pm 8.02 years), after myocardial infarction, who underwent percutaneous coronary angioplasty. The tests were performed during the second stage of rehabilitation. All participants of the experiment were qualified for model A (exercise test result $\geq 7 \mathrm{MET}$ or $100 \mathrm{~W}$ ). Reducing the number of confounding factors, such as age, sex, disease entity, treatment method, and level of exercise tolerance, patients included in the study were randomized to two rehabilitation procedures:

- standard rehabilitation (group ST) - 32 people

- indoor cycling training (group IC)-32 people

Inclusion criteria consent to participate in the study, documented stable ischemic heart disease or an uncomplicated course of myocardial infarction, time from the last cardiovascular event $<2$ months, stress test result $\geq 7 \mathrm{MET} / 100 \mathrm{~W}$, left ventricular ejection fraction $(\mathrm{LVEF}) \geq 50 \%$. Exclusion criteria: refusal to participate in the study, recent myocardial infarction, LVEF $<50 \%$, coronary artery bypass surgery, unregulated hypertension, unstable coronary artery disease, arrhythmias and conduction disturbances, established cancer, diseases of the central or peripheral nervous system, varicose veins of the lower limbs, osteoarthritis of the peripheral joints and the spine, unhealed injuries of the lower limbs, advanced peripheral arteriosclerosis, age $\geq 75$ and incomplete medical documentation. 


\section{Experimental procedure}

Both the standard group and the IC group were subjected to a 24-day improvement program, which included 22 training units ( 2 days for initial and final tests) performed 5 times a week following ESC standards (a detailed training program is presented in Table 1 . Throughout the entire research procedure, the patients were supervised by medical personnel consisting of a physiotherapist and a cardiologist.

The intensity of the exercise varied on the basis of the calculated training heart rate, starting from $60 \%$ of the heart rate reserve, increasing by $10 \%$ after 5 training units, up to $80 \%$ of the heart rate reserve, up to a maximum of 15 according to the Borg scale.

Endurance training on a bicycle ergometer (Kettler Ergometer X1) began with a 3-min ride without load $(0 \mathrm{~W})$, followed by 5 cycles-a 3-min load phase and a 2-min rest phase, a total of $25 \mathrm{~min}$ of riding. The training session ended with 2 min of cycling without load. The training on a bicycle ergometer lasted a total of $30 \mathrm{~min}$. After each training unit, stretching of the muscle groups involved during the ride was performed ( $5 \mathrm{~min}$ ). People from the IC group performed indoor cycling training (Tomahawk I.C.E. Indoor Cycling) instead of the traditional interval training. The training ride lasted $30 \mathrm{~min}$ in total and started with a 5-min warm-up with no load, in the rhythm of 100-110 RPM. The main part included cycling to the rhythm of changing music, including sitting and standing positions, and lasted $22.5 \mathrm{~min}(60-110 \mathrm{RPM})$. The main part was followed by a 2.5 -min cool down with a gradually decreasing load. The cycling cadence (RPM) was determined by the rhythm beats (BPM) present in each piece, being an important motivating instrument; moreover, the cadence of the rotation was signaled by the instructor. The unit ended with 5 min of stretching of the muscle groups-the muscles of the chest, back, quadriceps and biceps muscles of the thigh, as well as the buttocks, forearms and arms. The stretching was performed on mats placed on the dance floor. Details of the training protocol are presented in Table 2. Patients from the experimental group also participated in the other two forms of training (resistance and general improvement), as did the control group (Table 1).

The following was carried out before commencing the training program and immediately after its completion:

- Electrocardiographic exercise test on a treadmill (sixstage Bruce protocol: stage $1=2.7 \mathrm{~km} / \mathrm{h}, 10 \%$, stage $2=4.0 \mathrm{~km} / \mathrm{h}, 12 \%$, stage $3=5.5 \mathrm{~km} / \mathrm{h}, 14 \%$, stage $4=6.8 \mathrm{~km} / \mathrm{h}, 16 \%$, stage $5=8.0 \mathrm{~km} / \mathrm{h}, 18 \%$, stage $6=8.8 \mathrm{~km} / \mathrm{h}, 20 \%$ ) Exercise test using the Excalibur Sport cycle ergometer (Lode, Groningen, The Netherlands) [18]. The following were measured: test duration ( $\mathrm{min})$, distance covered ( $\mathrm{m}$ ), energy cost (MET), heart rate at rest and maximum (BPM), systemic blood pressure at rest and maximum ( $\mathrm{mmHg}$ ), criteria for ending the test (physiological: submaximum heart rate, i.e., $85 \%$ of HRmax determined on the basis of the following formula: 208-0.7 $\times$ age or fatigue; pathological: stenocardial pain, ST segment, and T-wave changes, rhythm and/or conduction disorders, blood pressure increase above 250/120 $\mathrm{mmHg}$ ), maximum oxygen uptake $\left(\mathrm{VO}_{2} \mathrm{max}\right)$.

- Two-dimensional ultrasound heart test, measured hemodynamic parameters (GE Vivid Q): left ventricular end-diastolic dimension (LVEDD; $\mathrm{mm}$ ), left ventricular end-systolic dimension (LVESD; mm), left ventricular end-systolic volume (LVESV; mL) as per the following formula:

LVESV $=7 /(2.4+$ LVESD $)-($ LVESD $)$, left ventricular end-diastolic volume (LVEDV; mL)

Table 1 Training following ESC recommendations

\begin{tabular}{|c|c|c|}
\hline Type of training & Methodology & Workload \\
\hline Endurance training & $\begin{array}{l}\text { Training on a bicycle ergometer, } \\
5 \text { times a week } \\
30 \text { min }\end{array}$ & \multirow{3}{*}{$\begin{array}{l}\text { Workload applied on the basis of calculation of heart rate training, starting from } \\
60 \% \text { of heart rate reserve increased by } 10 \% \text { after } \\
5 \text { units of training, } \\
\text { to } 80 \% \text { of heart rate reserve, } \\
14 \text { degrees of subjective scale effort assessment by the Borg scale }\end{array}$} \\
\hline Resistance training & $\begin{array}{l}\text { Exercises in the form of training station, } \\
5 \text { times a week } \\
30 \text { min }\end{array}$ & \\
\hline General exercises & $\begin{array}{l}\text { Exercises in the gym-elements of aerobic } \\
\text { and anaerobic training, stretching, breathing } \\
\text { exercises, } \\
5 \text { times a week } \\
30 \text { min }\end{array}$ & \\
\hline
\end{tabular}


Table 2 Protocol of the indoor cycling training unit

\begin{tabular}{|c|c|c|c|c|}
\hline Part of the training session & Time (min) & Borg scale & RPM & Position/technique \\
\hline Warm-up & $1-5$ & $9-10$ & $100-110$ &  \\
\hline \multirow[t]{14}{*}{ Appropriate training } & \multirow[t]{3}{*}{$5-10$} & \multirow[t]{3}{*}{$12-13$} & 110 & Position ja 1 (2 min) \\
\hline & & & 110 & Position a 2 (2 min) \\
\hline & & & 80 & Position a 2-SC (1 min) \\
\hline & \multirow[t]{5}{*}{$10-17.5$} & \multirow[t]{5}{*}{$12-14$} & 80 & Position a 3 - StC ( $1 / 2 \mathrm{~min})$ \\
\hline & & & $100-110$ & Position a 1 (2⿺辶⿸厃㔾min) \\
\hline & & & 100 & Position a 2 (21ำmin) \\
\hline & & & $60-80$ & Position a $3 \mathrm{StC}(1 / 2 \mathrm{~min})$ \\
\hline & & & 100 & Position 1 (11/2min) \\
\hline & \multirow[t]{3}{*}{$17.5-22.5$} & \multirow[t]{3}{*}{$13-14$} & $60-80$ & Position ja 2-SC (1 min) \\
\hline & & & 100 & Position 2 (31ำmin) \\
\hline & & & 80 & Position 3-StC (1/2min) \\
\hline & \multirow[t]{3}{*}{$22.5-27.5$} & \multirow[t]{3}{*}{$11-12$} & 80 & Position 2 (2 min) \\
\hline & & & $60-80$ & Position a 2-SC (2 min) \\
\hline & & & $100-110$ & Position a 2 (1 min) \\
\hline Cool down & $27.5-30$ & $9-10$ & 100 & Position a 1 -SF \\
\hline Stretching & $30-35$ & 9 & - & - \\
\hline
\end{tabular}

min minute, position 1 close, position 2 open, position 3 standing, RPM revolutions per minute, SC seated climb, SF seated flat, StC standing climb, StF standing flat

as per the following formula: $L V E D V=7 /$ $(2.4+$ LVEDD) - (LVEDD), left ventricular ejection fraction (LVEF; \%), left ventricular mass (LVM; g), left ventricular mass index (LVMI; $\mathrm{g} / \mathrm{m}^{2}$ ) based on the Devereux formula: $\mathrm{LVMI}=\mathrm{LVM} / \mathrm{BSA}$ (left ventricular mass/body surface area).

- Blood lipid profile test. Measured parameters:

Total cholesterol-TC (mg/dL), high-density lipoproteins-HDL (mg/dL), low-density lipoproteins-LDL $(\mathrm{mg} / \mathrm{dL})$, triglycerides-TG $(\mathrm{mg} / \mathrm{dL})$.

Before, during and immediately after each training session, heart rate (Polar, FT1) and blood pressure (SOHO, 110 HS-50A) measurements were made, as well as the degree of perception of effort according to the 20-point Borg scale. The intensity of the exercise varied on the basis of the calculated training heart rate, starting from $60 \%$ of the heart rate reserve, increasing by $10 \%$ after 5 training units, up to $80 \%$ of the heart rate reserve, up to a maximum of 15 according to the Borg scale.

The following was carried out before commencing the training program and immediately after its completion:

- Electrocardiographic exercise test on a treadmill (six-stage Bruce protocol: stage $1=2.7 \mathrm{~km} / \mathrm{h}, 10 \%$, stage $2=4.0 \mathrm{~km} / \mathrm{h}, 12 \%$, stage $3=5.5 \mathrm{~km} / \mathrm{h}, 14 \%$, stage $4=6.8 \mathrm{~km} / \mathrm{h}, 16 \%$, stage $5=8.0 \mathrm{~km} / \mathrm{h}, 18 \%$, stage $6=8.8 \mathrm{~km} / \mathrm{h}, 20 \%)$ Exercise test using the Excalibur Sport cycle ergometer (Lode, Groningen, The Netherlands) [18]. The following were measured: test duration (min), distance covered (m), energy cost (MET), heart rate at rest and maximum (BPM), systemic blood pressure at rest and maximum $(\mathrm{mmHg})$, criteria for ending the test (physiological: submaximum heart rate, i.e., $85 \%$ of HRmax determined on the basis of the following formula $208-0.7 x$ age or fatigue; pathological: stenocardial pain, ST segment, and T-wave changes, rhythm and/or conduction disorders, blood pressure increase above 250/120 $\mathrm{mmHg}$ ), $\mathrm{VO}_{2} \max$.

- Two-dimensional ultrasound heart test, measured hemodynamic parameters (GE Vivid Q): LVEDD $(\mathrm{mm})$, LVESD $(\mathrm{mm})$, LVESV $(\mathrm{mL})$ as per the following formula:

$$
\text { LVESV }=7 /(2.4+\text { LVESD })-(\text { LVESD }), \operatorname{LVEDV~}(\mathrm{mL})
$$

as per the following formula: $L V E D V=7 /$ (2.4 + LVEDD) - (LVEDD), LVEF (\%), left ventricular mass (LVM; g), left ventricular mass index (LVMI; g/ $\mathrm{m}^{2}$ ) based on the Devereux formula: LVMI $=$ LVM/BSA (left ventricular mass/body surface area).

- Blood lipid test profile. Measured parameters: 
Table 3 Characteristics of both groups

\begin{tabular}{lcc}
\hline Variable & Group IC $(\mathbf{N}=\mathbf{3 2})$ & Group ST $\mathbf{~} \mathbf{N}=\mathbf{3 2})$ \\
\hline Age (years) & $53.40 \pm 4.31(38-74)$ & $55.31 \pm 6.45(41-72)$ \\
Height $(\mathrm{cm})$ & $177 \pm 4.66(169-189)$ & $178.20 \pm 7.55(163-188)$ \\
Weight $(\mathrm{kg})$ & $85.65 \pm 7.55(72-101)$ & $86.09 \pm 13.22(66.90-111.24)$ \\
BMI (kg/m²) & $26.48 \pm 1.61(22.28-33.42)$ & $27.82 \pm 6.63(22.80-31.23)$ \\
LVEF (\%) & $55.22 \pm 5.95(51-59)$ & $54.50 \pm 8.44(52-58)$
\end{tabular}

$B M I$ body mass index, $N$ number, $L V E F$ left ventricular ejection fraction

Table 4 Disease entities occurring in patients of both groups

\begin{tabular}{lll}
\hline Type & $\begin{array}{l}\text { Group IC } \\
\text { N (\%) }\end{array}$ & $\begin{array}{l}\text { Group ST } \\
\mathbf{N}(\%)\end{array}$ \\
\hline Ischemic heart disease & $27(84.3 \%)$ & $28(87.5 \%)$ \\
Type 2 diabetes & $6(18.75 \%)$ & $8(25 \%)$ \\
Hyperlipidemia & $9(28.12 \%)$ & $11(34.37 \%)$ \\
Hypertension & $14(43.75 \%)$ & $18(56.25 \%)$ \\
Myocardial infarction & $32(100 \%)$ & $32(100 \%)$ \\
\hline
\end{tabular}

Table 5 Type of myocardial infarction

\begin{tabular}{lll}
\hline Type & $\begin{array}{l}\text { Group IC } \\
\mathbf{N}(\%)\end{array}$ & $\begin{array}{l}\text { Group ST } \\
\mathbf{N}(\%)\end{array}$ \\
\hline NSTEMI & $26(81.25 \%)$ & $28(87.5 \%)$ \\
STEMI & $6(18.75 \%)$ & $4(12.5 \%)$ \\
Total & $32(100 \%)$ & $32(100 \%)$ \\
\hline
\end{tabular}

NSTEMI non-ST elevation myocardial infarction, STEMI ST elevation myocardial infarction

total cholesterol-TC $(\mathrm{mg} / \mathrm{dL})$, high-density lipoproteins-HDL (mg/dL), low-density lipoproteins-LDL $(\mathrm{mg} / \mathrm{dL})$, triglycerides-TG $(\mathrm{mg} / \mathrm{dL})[18]$

\section{Data analysis}

The Shapiro-Wilk normality test and the Brown-Forsythe variance homogeneity test were used to verify the assumptions of parametric tests. The parametric Student's $t$ test was also performed for dependent variables whose distribution conformed to a normal distribution, and a nonparametric Wilcoxon paired order test was performed for dependent variables whose distribution did not conform to a normal distribution. Student's t-test was also performed for independent variables whose distribution conformed to a normal distribution, and its nonparametric equivalent. The Mann-Whitney U-test was performed for independent variables whose distribution did not conform to a normal distribution. Statistica 12 (StatSoft, Kraków, Poland) software was used in the study. The assumed level of significance was $p_{-} 0.05$.
Table 6 Number of implanted stents

\begin{tabular}{lll}
\hline Number & $\begin{array}{l}\text { Group IC } \\
\mathbf{N}(\%)\end{array}$ & $\begin{array}{l}\text { Group ST } \\
\mathbf{N}(\%)\end{array}$ \\
\hline 1 & $27(84.37 \%)$ & $28(87.5 \%)$ \\
2 & $4(12.51 \%)$ & $4(12.5 \%)$ \\
$\geq 3$ & $1(3.12 \%)$ & $0(0 \%)$ \\
\hline
\end{tabular}

\section{Results}

The characteristics of the subject are presented in the Tables 3, 4 and 5 .

Ischemic disease and myocardial infarction were dominant in both groups (Table 6).

Implantation of 1 stent was predominant in all groups.

Table 7 shows the results for the two test groups of the treadmill exercise test as per the classical Bruce protocol. In both analyzed groups, after the completion of the rehabilitation programs, a statistically significant increase in test duration, energy cost (MET) and $\mathrm{VO}_{2}$ max was demonstrated in relation to the baseline test.

The results of the echocardiographic examination are presented in Table 8. In both studied groups, improvement in the analyzed hemodynamic parameters of the left ventricle, however, were not statistically significant. There was also no significant difference in intergroup comparisons.

The analysis of changes in the lipid profile (Table 9) showed a favorable direction of changes in the values of all assessed indicators. However, these changes did not show statistically significant features.

\section{Discussion}

There are a small number of publications on the impact of alternative forms of endurance training used in the second stage of rehabilitation on the level of exercise tolerance, hemodynamic parameters of the left ventricle, or the lipid profile of patients after a myocardial infarction $[4,6]$.

Never before has such an assessment been made of indoor cycling training.

Until now, this form was available and associated only with the population of healthy people who attended classes in fitness clubs. It has many features in common with traditional endurance training that has been used for years in a cardiac rehabilitation program. These include: the interval training form, HR-controlled work intensity, the ability to control and dose external resistance, individual or group training form, constant monitoring of vital signs ( $\mathrm{HR}, \mathrm{SpO}_{2}$, blood pressure, $\mathrm{Bf}$ ), low risk of injury. What makes it stand out is primarily the way it is run. It is possible to ride sitting and standing, as well as to adjust the height of the saddle and handlebars 
Table 7 Results of the treadmill exercise test in three groups of patients before (I) and at the end (II) of cardiac rehabilitation

\begin{tabular}{|c|c|c|c|c|c|}
\hline Variable & $\begin{array}{l}\text { IC group } \\
X \pm S D\end{array}$ & $p$ & $\begin{array}{l}\text { ST group } \\
X \pm \text { SD }\end{array}$ & $p$ & $\begin{array}{l}\Delta \mathrm{IC} \text { versus } \Delta \mathrm{ST} \\
p \text { value }\end{array}$ \\
\hline Time I & $9.21 \pm 2.02$ & $<0.001$ & $9.41 \pm 0.39$ & $<0.001$ & 0.772 \\
\hline Time II & $11.24 \pm 1.26$ & & $10.91 \pm 2.22$ & & \\
\hline$\Delta(\min )$ & 2.03 & & 1.50 & & \\
\hline METI & $9.16 \pm 1.30$ & 0.006 & $8.65 \pm 0.25$ & 0.002 & 0.873 \\
\hline MET II & $10.73 \pm 1.23$ & & $9.86 \pm 1.12$ & & \\
\hline$\triangle \mathrm{MET}$ & 1.57 & & 1.21 & & \\
\hline HRrest I & $66.32 \pm 9.16$ & 0.862 & $70.11 \pm 8.15$ & 0.790 & 0.899 \\
\hline HRrest II & $65.30 \pm 10.31$ & & $68.40 \pm 7.71$ & & \\
\hline$\Delta$ (beats/minute) & -1.02 & & -1.71 & & \\
\hline HRmax I & $128.25 \pm 14.79$ & 0.169 & $128.55 \pm 14.69$ & 0.264 & 0.992 \\
\hline HRmax II & $133.65 \pm 16.37$ & & $133.75 \pm 11.10$ & & \\
\hline$\Delta$ (beats/minute) & 5.4 & & 5.2 & & \\
\hline SBPrest I & $124.60 \pm 11.59$ & 0.999 & $124.40 \pm 13.96$ & 0.936 & 0.914 \\
\hline SBPrest II & $125.45 \pm 18.11$ & & $123.88 \pm 2.38$ & & \\
\hline$\Delta(\mathrm{mmHg})$ & 0.85 & & -0.52 & & \\
\hline DBPrest I & $82.10 \pm 6.52$ & 0.984 & $79.25 \pm 4.16$ & 0.918 & 0.918 \\
\hline DBPrest II & $81.05 \pm 7.26$ & & $79.34 \pm 6.27$ & & \\
\hline$\Delta(\mathrm{mmHg})$ & -1.05 & & 0.09 & & \\
\hline SBPmax I & $169.25 \pm 11.30$ & 0.663 & $158.50 \pm 10.15$ & 0.730 & 0.114 \\
\hline SBPmax II & $174.09 \pm 12.25$ & & $162.33 \pm 13.53$ & & \\
\hline$\Delta(\mathrm{mmHg})$ & 4.84 & & 3.83 & & \\
\hline DBPmax I & $84.21 \pm 6.48$ & 0.954 & $83.85 \pm 6.50$ & 0.916 & 0.922 \\
\hline DBPmax II & $82.20 \pm 9.33$ & & $82.09 \pm 6.18$ & & \\
\hline$\Delta(\mathrm{mmHg})$ & -2.01 & & -1.76 & & \\
\hline $\mathrm{VO}_{2} \max I$ & $37.27 \pm 3.23$ & $<0.001$ & $36.89 \pm 6.22$ & $<0.001$ & 0.167 \\
\hline $\mathrm{VO}_{2} \max \|$ & $39.10 \pm 3.17$ & & $38.76 \pm 3.44$ & & \\
\hline$\Delta(\mathrm{ml} / \mathrm{kg} / \mathrm{min})$ & 1.83 & & 1.87 & & \\
\hline
\end{tabular}

All data are presented as means \pm standard deviation and the difference $(\Delta-$ delta)

MET metabolic equivalent, $H$ Rrest resting heart rate, $H R$ max maximum heart rate, DBPmax maximum diastolic blood pressure, $D B P$ rest resting diastolic blood pressure, SBPmax maximum systolic blood pressure, SBPrest resting systolic blood pressure, $\mathrm{VO}_{2}$ max maximal oxygen uptake

and the distance between the saddle and the handlebars, which makes it an ideal training device for people regardless of their constitutional body build [7-9]. The results obtained after the end of the cardiac rehabilitation program, in which indoor cycling was used, showed that it is a safe, effective and well-tolerated form of endurance exercise, which can be recommended in the process of comprehensive rehabilitation of patients after a heart attack.

\section{Electrocardiographic exercise test}

The results obtained after 24 days of implementation of the rehabilitation program showed a significant improvement in physical capacity compared to the results obtained before its commencement. In both analyzed groups, i.e. the IC group and the ST group, a significant increase in test duration was obtained (respectively: $9.21 \pm 2.02$ vs $11.24 \pm 1.26$ min; $p<0.001$ and $9.41 \pm 0.39$ vs $10.91 \pm 2.22 \mathrm{~min} ; p<0.001)$. The extension of its duration is an effect that confirms the high effectiveness of the applied rehabilitation models and proves the expected increase in exercise tolerance. Another indicator showing the improvement of the physical capacity of patients, which significantly improved in both studied groups, is metabolic equivalents (MET) (IC group-9.16 \pm 1.30 vs $10.73 \pm 1.23, p=0.006$; ST group $-8.65 \pm 0.25$ vs $9.86 \pm 1.12 ; p=0.002)$.

The myocardial oxygen demand depends on the heart rate, the tension of the left ventricular wall and the contractility of the heart muscle. According to Myers et al. [19] peak exercise capacity measured in MET is the strongest prognostic factor for the risk of death both among healthy people and those with cardiovascular diseases, including those after myocardial infarction. A favorable increase in the value of MET after the 
Table 8 Results of echocardiographic tests carried out before (I) and after (II) the 24-day rehabilitation cycle

\begin{tabular}{|c|c|c|c|c|c|}
\hline Variable & $\begin{array}{l}\text { IC group } \\
X \pm S D\end{array}$ & $p$ & $\begin{array}{l}\text { ST group } \\
X \pm S D\end{array}$ & $p$ & $\begin{array}{l}\Delta \mathrm{IC} \text { versus } \\
\Delta \mathrm{ST} \\
p \text { value }\end{array}$ \\
\hline LVEDD I & $49.98 \pm 3.60$ & 0.918 & $50.33 \pm 4.12$ & 0.843 & 0.825 \\
\hline LVEDD ॥ & $50.21 \pm 3.34$ & & $50.95 \pm 3.23$ & & \\
\hline$\Delta(\mathrm{mm})$ & 0.23 & & 0.62 & & \\
\hline LVESD I & $32.71 \pm 4.64$ & 0.933 & $33.22 \pm 3.11$ & 0.773 & 0.818 \\
\hline LVESD ॥ & $32.89 \pm 7.83$ & & $33.75 \pm 3.28$ & & \\
\hline$\Delta(\mathrm{mm})$ & 0.18 & & 0.53 & & \\
\hline LVESV I & $44.33 \pm 21.34$ & 0.932 & $47.22 \pm 11.21$ & 0.892 & 0.899 \\
\hline LVESV II & $45.11 \pm 16.97$ & & $48.01 \pm 10.01$ & & \\
\hline$\Delta(\mathrm{ml})$ & 0.78 & & 0.79 & & \\
\hline LVEDV I & $116.32 \pm 22.52$ & 0.911 & $121.12 \pm 23.22$ & 0.902 & 0.948 \\
\hline LVEDV II & $117.44 \pm 14.66$ & & $122.43 \pm 14.38$ & & \\
\hline$\Delta(\mathrm{ml})$ & 1.12 & & 1.31 & & \\
\hline LVSV I & $84.12 \pm 27.60$ & 0.991 & $94.92 \pm 31.43$ & 0.981 & 0.932 \\
\hline LVSV II & $84.01 \pm 21.11$ & & $94.12 \pm 13.34$ & & \\
\hline$\Delta(\mathrm{ml})$ & -0.11 & & -0.8 & & \\
\hline LVEF I & $55.22 \pm 5.95$ & 0.117 & $54.50 \pm 8.44$ & 0.197 & 0.911 \\
\hline LVEF ॥ & $56.45 \pm 2.68$ & & $55.75 \pm 9.44$ & & \\
\hline$\Delta(\%)$ & 1.23 & & 1.25 & & \\
\hline LVM I & $180.56 \pm 81.11$ & 0.998 & $191.43 \pm 19.33$ & 0.935 & 0.989 \\
\hline LVM II & $181.34 \pm 22.46$ & & $192.19 \pm 23.91$ & & \\
\hline$\Delta(\mathrm{g})$ & 0.78 & & 0.76 & & \\
\hline LVMI I & $89.64 \pm 22.45$ & 0.917 & $95.47 \pm 16.75$ & 0.933 & 0.886 \\
\hline LVMI II & $90.33 \pm 14.36$ & & $96.09 \pm 54.64$ & & \\
\hline$\Delta\left(\mathrm{g} / \mathrm{m}^{2}\right)$ & 0.69 & & 0.62 & & \\
\hline
\end{tabular}

LVEDD left ventricular end-diastolic diameter, LVESD left ventricular end-systolic diameter, LVESV left ventricular end-systolic volume, LVEDV left ventricular end-diastolic volume, LVSV left ventricular stroke volume, LVEF left ventricular ejection fraction, LVM left ventricular mass, LVMI left ventricular mass index

Table 9 Results of blood lipid profile tests carried out before (I) and after (II) the 24-day rehabilitation cycle

\begin{tabular}{llllll}
\hline Variable & $\begin{array}{l}\text { IC group } \\
\mathbf{X} \pm \text { SD }\end{array}$ & $\boldsymbol{p}$ & $\begin{array}{l}\text { ST group } \\
\mathbf{X} \pm \text { SD }\end{array}$ & $\boldsymbol{p}$ & $\begin{array}{l}\boldsymbol{\Delta} \text { IC versus } \\
\boldsymbol{\Delta} \text { ST } \\
\boldsymbol{p} \text { value }\end{array}$ \\
\hline $\mathrm{TCI}$ & $182.24 \pm 26.41$ & 0.249 & $172.27 \pm 45.34$ & 0.113 & 0.601 \\
$\mathrm{TC} \mathrm{I}$ & $171.67 \pm 10.39$ & & $166.23 \pm 66.29$ & & \\
$\Delta(\mathrm{mg} / \mathrm{dl})$ & -10.57 & & -6.04 & & \\
$\mathrm{HDL}$ I & $44.21 \pm 19.07$ & 0.142 & $43.23 \pm 24.56$ & 0.158 & 0.893 \\
$\mathrm{HDL} \|$ & $48.34 \pm 19.27$ & & $47.88 \pm 17.66$ & & \\
$\triangle(\mathrm{mg} / \mathrm{dl})$ & 4.13 & & 4.65 & & \\
$\mathrm{LDLI}$ & $111.23 \pm 19.44$ & 0.223 & $104.39 \pm 24.34$ & 0.223 & 0.367 \\
$\mathrm{LDL} \|$ & $99.62 \pm 26.12$ & & $91.47 \pm 13.04$ & & \\
$\triangle(\mathrm{mg} / \mathrm{dl})$ & -11.61 & & -12.92 & & \\
$\mathrm{TGI}$ & $121.35 \pm 71.37$ & 0.815 & $126.22 \pm 21.56$ & 0.793 & 0.829 \\
$\mathrm{TG} \mathrm{II}$ & $115.15 \pm 45.32$ & & $119.48 \pm 14.59$ & & \\
$\triangle(\mathrm{mg} / \mathrm{dl})$ & -6.2 & & -6.74 & & \\
\hline
\end{tabular}

$T C$ total cholesterol, $H D L$ high-density lipoproteins, $L D L$ low-density lipoproteins, TG triglycerides completion of the second stage cardiac rehabilitation program was also observed in the retrospective analysis of the results of 10,671 patients, regardless of their initial level of exercise tolerance [20]. A similar effect associated with the increase in MET was observed in the evaluation of the effects of hybrid rehabilitation of 125 patients with heart failure [21]. The increase in MET energy expenditure at a similar level was also demonstrated in the studies by Nowak et al. [4] and Grabara et al. [6], who also assessed the effectiveness of alternative training methods in cardiac rehabilitation of patients after myocardial infarction. Maximum oxygen uptake $\left(\mathrm{VO}_{2} \mathrm{max}\right)$, also referred to as the body's aerobic capacity, is a real measure of exercise tolerance and, at the same time, an indicator of the cardiovascular system efficiency [4]. It provides objective information about the clinical condition and factors limiting the possibilities of a cardiac patient [22]. A maximum oxygen intake of $10 \mathrm{~mL} / \mathrm{kg} /$ min represents severe heart failure. The minimum level of physical activity assessed via $\mathrm{VO}_{2} \max$ is $40 \mathrm{~mL} / \mathrm{kg} /$ min. For a person with a sedentary lifestyle, $\mathrm{VO}_{2} \mathrm{max}$ is approximately $30 \mathrm{ml} / \mathrm{kg} / \mathrm{min}$. The results of our research showed an increase (about $8 \%$ ) in the $\mathrm{VO}_{2}$ max value in both groups (IC group $37.27 \pm 3.23$ vs $39.10 \pm 3.17 \mathrm{ml} / \mathrm{kg}$ / min; $p<0.001$, ST group: $36.89 \pm 6.22 \mathrm{vs} 38.76 \pm 3.44 \mathrm{ml} /$ $\mathrm{kg} / \mathrm{min} ; p<0.001)$. Endurance training increases oxygen uptake. It is the result of an increased capillary arteriovenous difference and an increase in cardiac output [23]. In the group of healthy people, the increase in $\mathrm{VO}_{2}$ max by $8-15 \%$ is the result of properly planned training. The similar increase achieved in our research proves that a properly planned rehabilitation program carried out in a continuous and systematic manner significantly improved the level of physical fitness of patients. This is also confirmed in the research by other authors [24-27]. The intergroup analysis did not show any statistically significant differences in the results of the research in terms of individual indicators.

\section{Echocardiographic test}

The result of myocardial infarction is impairment of the mechanical function of the myocardium and progressive structural changes in the myocardium (called remodeling), which affect all parts of the cardiovascular system equally [28]. Altered hemodynamic conditions (for instance reduction of left ventricular stroke volume-LVSV, enhancement of LVEDV) and increased activity of the renin-angiotensin-aldosterone and catecholamines consistently contribute to impaired diastolic function of the heart, thus affecting the systolic function with a reduction in LVEF in total. First of all, the activity of aldosterone leads to the replacement of contractile muscle tissue with an excess of connective tissue with a 
predominance of collagen, which initially is an adaptive response, and later may take the form of pathological heart failure [29]. In addition to stimulating the reninangiotensin-aldosterone system, diabetes mellitus, anterior infarction and its extensive early spread, and persistent occlusion of the intra-infarct artery exacerbate adverse myocardial remodeling. Reconstruction, and, more specifically, enlargement of the left ventricle silhouette may be a significant prognostic factor; therefore the assessment of its dimensions and functions should be routinely performed in most cardiological diseases. The study assessed the indicators of the left ventricle of the heart muscle. There were statistically insignificant increases in mean values of LVEDD, LVESD, LVESV, LVEDV, LVEF, LVMI, LVMI and a slight decrease in LVSV in both rehabilitated groups, which indicates a positive rehabilitation effect. It should be emphasized, however, that it is still ambiguous to determine the impact of physical activity (primarily of the endurance type) on the post-infarction structure and functions of the left ventricle [30]. The causes of this problem may include differences in the methodology of research carried out by different authors. The differences in the obtained results may be influenced by factors such as selection of the population, the extent of myocardial infarction, the age of the respondents, the period covered by the observation, measurement techniques and a combination of any of the above-mentioned factors. Similar conclusions were reached by Gates et al. [31], Belardinelli et al. [32] and Nowak et al. [33]. With the exception of the ejection fraction of the left ventricle, they did not observe any significant changes in the diastolic function of the left ventricle under the influence of training, even in relation to physically more or less active patients.

In conclusion, the influence of physical training on the heart has not been clearly explained. Most studies, including ours, failed to demonstrate a significant effect of physical training on the morphological and functional parameters of the left ventricle, or it was found that physical activity only slightly improved them. As in the case of the exercise test, the intergroup analysis showed no statistically significant differences.

\section{Examination of the lipid profile}

Increased levels of total cholesterol and triglycerides are factors in the formation of atherosclerotic lesions in the coronary, cerebral and peripheral vessels. Their concentrations in blood serum are determined heredity, but a significant role in lowering the levels is attributed to lifestyle elements (environmental factors), such as a proper diet and systematic physical activity [34, 35]. Scientific reports confirm the beneficial effect of physical activity on the lipid profile, although it concerns longer observations, e.g. 6 months [32, 33]. In the case of observations that cover a short period of time, the changes are not statistically significant, which was also the case in our own research. It is also difficult to say whether the reason for the changes observed is the rehabilitation program or the effect of statins. Comparing the results of the tests before and after the start of rehabilitation, the level of the analyzed lipids in both cases was within the normal range, which may be even more indicative of the earlier undertaking of pharmacological treatment.

\section{Limitation}

A limitation of the study was the inclusion of only a single group of patients with a high level of physical capacity $\geq 7$ MET or $\geq 100$ W. However, the results, which confirmed the effectiveness of indoor cycling training included in the cardiac rehabilitation program of patients after myocardial infarction, certainly warrant additional studies in this field, which will assess patient groups with lower physical capacity than those included in our study. A second limitation is the inclusion of the male study participants only. This was a select group of patients (see exclusion criteria) and may not be representative of a general cardiac rehabilitation population. Studies involving a large group of participants of both sexes with various levels of physical capacity and clinical status are needed.

In the future, research should also be undertaken to determine which of the indoor cycling techniques and profile is the most appropriate for cardiac patients.

\section{Practical recommendation}

Indoor cycling training is a form of training that has many features in common with traditional endurance training used in cardiac rehabilitation. The obtained results also showed similarity in terms of changes in exercise tolerance, left ventricular hemodynamics and lipid profile. Therefore, it may be a more interesting and attractive alternative to traditional endurance training in patients after a heart attack.

\section{Conclusions}

1. Both indoor cycling training and standard training have a similar effect on the improvement of exercise tolerance, change of hemodynamic indicators of the left ventricle and the lipid profile in patients after a heart attack.

2. Indoor cycling training can be an alternative to standard endurance training in cardiac rehabilitation. 


\section{Acknowledgements \\ Not applicable.}

\section{Authors' contributions}

Conceptualization, D.G. and Z.N.; methodology, T.G., P.V; software, A.N-L. and D.G; validation, T.G., and U.S.-G.; formal analysis, D.G. and A.P.; investigation, U.S.-G.; Z.N.; resources, D.G. and A.P.; data curation, T.G. and A.N-L. writing—original draft preparation, A.N.-L.; writing—review and editing, A.N.-L.; visualization, T.G. and A.P; supervision, T.G. and Z.N., P.V; project administration: U.S.-G.; funding acquisition, D.G. and Z.N. All authors have read and agreed to the published version of the manuscript.

\section{Funding}

This research received no external funding.

\section{Availability of data and materials}

Not applicable.

\section{Declarations}

\section{Ethics approval and consent to participate}

Ethical approval of the University Bioethics Commission for scientific research at J.Kukuczka Academy of Physical Education in Katowice (Poland) No. 7/2017 at 18/05/2017 was granted for conducting the study. The study was approved by the local Bioethics Committee and conformed to the standards set by the Declaration of Helsinki. All patients were informed about the type and aim of the study. Subjects were told that they may withdraw from the study at any time. The patients did not change their leisure physical activity, and medicaments were not modified during the study.

\section{Consent for publications}

Not applicable.

\section{Competing interests}

Not applicable.

\section{Author details}

${ }^{1}$ Silesian Center for Rehabilitation and Prevention, 43-450 Ustron, Poland. ${ }^{2}$ Department of Physiotherapy, Jerzy Kukuczka Academy of Physical Education, 40-065 Katowice, Poland. ${ }^{3}$ Sport Centrum Faculty of Pedagogy, University of West Bohemia, 30100 Pilsen, Czech Republic. ${ }^{4}$ Department of Anatomy, Faculty of Rehabilitation, University of Physical Education, 31-571 Kraków, Poland. ${ }^{5}$ Faculty of Health Science, Jan Dlugosz University, 42-200 Czestochowa, Poland.

Received: 7 May 2021 Accepted: 15 November 2021

Published online: 29 November 2021

\section{References}

1. el-Missiri A, Amin SA, Tawfik IR, Shabana AM. Effect of a 6-week and 12-week cardiac rehabilitation program on heart rate recovery. Egypt Heart J. 2020;72(1):69. https://doi.org/10.1186/s43044-020-00107-8.

2. Price KJ, Gordon BA, Bird SR, Benson AC. A review of guidelines for cardiac rehabilitation exercise programmes: is there an international consensus? Eur J Prev Cardiol. 2016;23(16):1715-33. https://doi.org/10.1177/20474 87316657669

3. Baumgärtner R. Cardiovascular rehabilitation-a current overview. Ther Umsch. 2019;76(8):415-23. https://doi.org/10.1024/0040-5930/a001114

4. Nowak A, Morawiec M, Gabrys T, Nowak Z, Szmatlan-Gabryś U, Salcman $\checkmark$. Effectiveness of resistance training with the use of a suspension system in patients after myocardial infarction. Int J Environ Res Public Health. 2020;17:5419. https://doi.org/10.3390/ijerph17155419.

5. Nowak-Lis A, Gabrys T, Nowak Z, Jastrzebski P, Szmatlan-Gabryś U, Konarska A, Grzybowska-Ganszczyk D, Pilis A. The use of artificial hypoxia in endurance training in patients after myocardial infarction. Int J Environ Res Public Health. 2021;18:1633. https://doi.org/10.3390/ijerph18041633.

6. Grabara M, Nowak Z, Nowak A. Effects of hatha yoga on cardiac hemodynamic parameters and physical capacity in cardiac rehabilitation patients.
J Cardiopulm Rehabil Prev. 2020;40(4):263-7. https://doi.org/10.1097/ HCR.0000000000000503.

7. Schmidt A. Indoor-cycling. Aachen: Meyer \& Meyer Verlag; 2008.

8. Günther M. Indoor-cycling: optimal trainieren für Kondition und Figur. München: Gräfe und Unzer; 2004

9. Silva RAS, Oliveira HB. Prevenção de lesões no ciclismo indoor - una proposta metodológica. Revista Brasileira de Ciência e Movimento. 2002;10(4):7-18.

10. Muyor JM. Exercise intensity and validity of the ratings of perceived exertion (Borg and OMNI scales) in an Indoor Cycling session. J Hum Kinet. 2013;39:93-101. https://doi.org/10.2478/hukin-2013-0072.

11. Deschamps SR, Domingues-Filho LA. Motivos e benefícios psicológicos que levam os indivíduos dos sexos masculino e feminino a praticarem o ciclismo indoor. Revista Brasileira de Ciência e Movimento. 2005;13(2):27-32.

12. Bianco A, Bellafiore M, Battaglia G, Paoli A, Caramazza G, Farina F, Palma A. The effects of indoor cycling training in sedentary overweight women. J Sport Med Phys Fitness. 2010;50(2):159-65.

13. López-Miñarro PA, Muyor JM. Heart rate and overall ratings of perceived exertion during Spinning cycle indoor session in novice adults. Sci Sports. 2010;25(5):238-44.

14. Valle VS, Mello DB, Fortes S, Dantas EHM, Mattos MA. Effect of diet and Indoor cycling on body composition and serum lipid. Arq Bras Cardiol. 2010;95(2):173-8. https://doi.org/10.1590/s0066-782x201005000080.

15. Valle VS, Mello DB, Fortes M, Dantas EHM. Effects of Indoor cycling associated with diet on body composition and serum lipids. Biomed Hum Kinet. 2009:1:11-5.

16. Vilarinho R, Souza WYG, Rodrigues TC, Ahlin JV, Junior DPG, Barbosa FM. Effects of indoor cycling in body composition, muscular endurance, flexibility, balance and daily activities in physically active elders. Fit Perform J. 2009:8(6):446-51.

17. Foster C, Andrew J, Battista RA, Porcari JP. Metabolic and perceptual responses to indoor cycling. J Cardiopulm Rehabil. 2006;26:270.

18. Nowak-Lis A, Gabryś T, Nowak Z, Jastrzebski P, Szmatlan-Gabryś U, Konarska A, Grzybowska-Ganszczyk D, Pilis A. The use of artificial hypoxia in endurance training in patients after myocardial infarction. Int J Environ Res Public Health. 2021;18:1633. https://doi.org/10.3390/ijerph18041633.

19. Myers J, Prakash M, Froelicher V, Do D, Partington S, Atwood JE. Exercise capacity and mortality among men referred for exercise testing. N Engl J Med. 2002;346(11):793-801. https://doi.org/10.1056/NEJMoa011858.

20. Abu-Haniyeh A, Shah NP, Wu Y, Cho L, Ahmed HM. Predictors of cardiorespiratory fitness improvement in phase II cardiac rehabilitation. Clin Cardiol. 2018;41:1563-9. https://doi.org/10.1002/clc.23101.

21. Szalewska D, Zielinski P, Tomaszewski J, Kusiak-Kaczmarek M, Łepska L, Gierat-Haponiuk K, Niedoszytko P. Effects of outpatient followed by home-based telemonitored cardiac rehabilitation in patients with coronary artery disease. Kardiol Pol. 2015;73:1101-7. https://doi.org/10.5603/ KP.a2015.0095.

22. Working Group Report. Recommendations for exercise testing in chronic heart failure patients. Eur Heart J. 2001;22:37-45. https://doi.org/10.1053/ euhj.2000.2388.

23. Poole DC, Barstow TJ, Gaesser GA, Willis WT, Whipp BJ. VO 2 slow component: physiological and functional significance. Med Sci Sport Exerc. 1994;26:1354-8.

24. Yang $X$, Li Y, Ren X, Xiong X, Wu L, Li J, Wang J, Gao Y, Shang H, Xing Y Effects of exercise-based cardiac rehabilitation in patients after percutaneous coronary intervention: a meta-analysis of randomized controlled trials. Sci Rep. 2017;7:1-9. https://doi.org/10.1038/srep44789.

25. Guazzi M, Adams V, Conraads V, Halle M, Mezzani A, Vanhees L, Arena R, Fletcher GF, Forman DE, Kitzman DW, Lavie CJ, Myers J. EACPR/AHA Scientific Statement. Clinical recommendations for cardiopulmonary exercise testing data assessment in specific patient populations. Circulation. 2012;126:2261-74. https://doi.org/10.1161/CIR.0b013e31826fb946.

26. Adams J, Cline M, Reed M, Masters A, Ehlke K, Hartman J. Importance of resistance training for patients after a cardiac event. Bayl Univ Med Cent Proc. 2006;19:246-8. https://doi.org/10.1080/08998280.2006.11928172.

27. Balady G, Arena R, Sietsema K, Myers J, Coke L, Fletcher GF, Forman D, Franklin B, Guazzi M, Gulati M, Keteyian SJ, Lavie CJ, Macko R, Mancini D, Milani RV. American Heart Association Exercise, Cardiac Rehabilitation, and Prevention Committee of the Council on Clinical Cardiology; Council on Epidemiology and Prevention; Council on Peripheral Vascular 
Disease; Interdisciplinary Council on Quality of Care and Outcomes Research. Clinician's Guide to cardiopulmonary exercise testing in adults: A scientific statement from the American Heart Association. Circulation. 2010;122:191-225. https://doi.org/10.1161/CIR.0b013e3181e52e69.

28. Florea VG, Mareyev VY, Samko AN, Orlova IA, Coats AJS, Belenkov YN. Left ventricular remodeling: common process in patients with different primary myocardial disorders. Int J Cardiol. 1999;68(3):281-7.

29. Huang BS, White RA, Ahmad M, Tan J, Jeng AY, Leenen FHH. Central infusion of aldosterone synthase inhibitor attenuates left ventricular dysfunction and remodelling in rats after myocardial infarction. Cardiovasc Res. 2009;81(3):574-81.

30. Sadeghi M, Garakyaraghi M, Khosravi M, Taghavi M, Sarrafzadegan N, Roohafza H. The impacts of cardiac rehabilitation program on echocardiographic parameters in coronary artery disease patients with left ventricular dysfunction. Cardiol Res Pract. 2013;2013: 201713. https://doi. org/10.1155/2013/201713.

31. Gates PE, Tanaka H, Graves J, Seals DR. Left ventricular structure and diastolic function with human ageing. Relation to habitual exercise and arterial stiffness. Eur Heart J. 2003;24(24):2213-20. https://doi.org/10. 1016/j.ehj.2003.09.026.

32. Belardinelli R, Paolini I, Cianci G, Piva R, Georgiou D, Purcaro A. Exercise training intervention after coronary angioplasty: the ETICA trial. J Am Coll Cardiol. 2001;37(7):1891-900. https://doi.org/10.1016/s0735-1097(01) 01236-0.

33. Nowak Z, Plewa M, Skowron M, Osiadlo G, Markiewicz A, Kucio C. Minnesota leisure time physical activity questionnaire as an additional tool in clinical assessment of patients undergoing percutaneous coronary interventions. J Hum Kinet. 2010;23:79-87.

34. Kinnear FJ, Lithander FE, Searle A, Bayly G, Wei C, Stensel DJ, Thackray $A E$, Hunt L, Shield JPH. Reducing cardiovascular disease risk among families with familial hypercholesterolaemia by improving diet and physical activity: a randomised controlled feasibility trial. BMJ Open. 2020;10(12):e044200. https://doi.org/10.1136/bmjopen-2020-044200

35. Bouillon K, Singh-Manoux A, Jokela M, Shipley MJ, Batty GD, Brunner EJ, Sabia S, Tabák AG, Akbaraly T, Ferrie JE, Kivimäki M. Decline in low-density lipoprotein cholesterol concentration: lipid-lowering drugs, diet, or physical activity? Evidence from the Whitehall II study. Heart. 2011;97(11):92330. https://doi.org/10.1136/hrt.2010.216309.

\section{Publisher's Note}

Springer Nature remains neutral with regard to jurisdictional claims in published maps and institutional affiliations.

Ready to submit your research? Choose BMC and benefit from:

- fast, convenient online submission

- thorough peer review by experienced researchers in your field

- rapid publication on acceptance

- support for research data, including large and complex data types

- gold Open Access which fosters wider collaboration and increased citations

- maximum visibility for your research: over $100 \mathrm{M}$ website views per year

At BMC, research is always in progress.

Learn more biomedcentral.com/submissions 